\title{
SYSTEMATIC MUTAGENESIS METHOD FOR ENHANCED PRODUCTION OF BACITRACIN BY BACILLUS LICHENIFORMIS MUTANT STRAIN UV-MN-HN-6
}

\author{
Muhammad Nauman Aftab ${ }^{1}$, Ikram-ul-Haq ${ }^{1}$, Shahjahan Baig ${ }^{2}$ \\ ${ }^{1}$ Institute of Industrial Biotechnology, Government College University, Lahore, Pakistan; ${ }^{2}$ Biotechnology and Food Research \\ Center, PCSIR Laboratories Complex, Lahore, Pakistan.
}

Submitted: January 05, 2010; Returned to authors for corrections: May 13, 2011; Approved: January 16, 2012.

\begin{abstract}
The purpose of the current study was intended to obtain the enhanced production of bacitracin by Bacillus licheniformis through random mutagenesis and optimization of various parameters. Several isolates of Bacillus licheniformis were isolated from local habitat and isolate designated as GP-35 produced maximum bacitracin production $\left(14 \pm 0.72 \mathrm{IU} \mathrm{ml}^{-1}\right)$. Bacitracin production of Bacillus licheniformis GP-35 was increased to $23 \pm 0.69 \mathrm{IU} \mathrm{ml}^{-1}$ after treatment with ultraviolet (UV) radiations. Similarly, treatment of vegetative cells of GP-35 with chemicals like N-methyl N'-nitro N-nitroso guanidine (MNNG) and Nitrous acid $\left(\mathrm{HNO}_{2}\right)$ increased the bacitracin production to a level of $31 \pm 1.35 \mathrm{IU} \mathrm{ml}^{-1}$ and $27 \pm 0.89 \mathrm{IU} \mathrm{ml}^{-1}$ respectively. Treatment of isolate GP-35 with combined effect of UV and chemical treatment yield significantly higher titers of bacitracin with maximum bacitracin production of $41.6 \pm 0.92 \mathrm{IU} \mathrm{ml}^{-1}$. Production of bacitracin was further enhanced $\left(59.1 \pm 1.35 \mathrm{IU} \mathrm{ml}^{-1}\right)$ by optimization of different parameters like phosphate sources, organic acids as well as temperature and $\mathrm{pH}$. An increase of 4.22 fold in the production of bacitracin after mutagenesis and optimization of various parameters was achieved in comparison to wild type. Mutant strain was highly stable and produced consistent yield of bacitracin even after 15 generations. On the basis of kinetic variables, notably $\mathrm{Y}_{\mathrm{p} / \mathrm{s}}$ (IU/g substrate), $\mathrm{Y}_{\mathrm{p} / \mathrm{x}}\left(\mathrm{IU} / \mathrm{g}\right.$ cells), $\mathrm{Y}_{\mathrm{x} / \mathrm{s}}$ $(\mathrm{g} / \mathrm{g}), \mathrm{Y}_{\mathrm{p} / \mathrm{s}}$, mutant strain B. licheniformis UV-MN-HN-6 was found to be a hyperproducer of bacitracin.
\end{abstract}

Key words: Mutagenesis, bacitracin, B. licheniformis, optimization

\section{INTRODUCTION}

Bacitracin $\left(\mathrm{C}_{66} \mathrm{H}_{103} \mathrm{~N}_{17} \mathrm{O}_{16} \mathrm{~S}\right)$ is metal dependent branched cyclic polypeptides (molecular weight 1470 daltons) produced by Bacillus licheniformis and Bacillus subtilis (3, 20, 29). It is synthesized non-ribosomally by the large multienzyme complex BacABC (24). Bacitracin is directed primarily against gram-positive bacteria via inhibition of cell wall $(5,28)$. Bacitracin consists of a mixture of structurally similar polypeptides from 12 amino acids (22). It is most commonly used in complex with zinc that seems to stabilize the antibiotic complex (18). It is poorly absorbed from gastrointestinal tract as well as from skin and nucosal surfaces (11).

Bacitracin was first discovered in 1943 and named

*Corresponding Author. Mailing address: Institute of Industrial Biotechnology, Government College University, Lahore, Pakistan.; E-mail: nauman535@yahoo.com 
after a culture of Bacillus and the last name of a 7 year old American girl, Margaret Tracey, from whose wounds the Bacillus was isolated (21). It is one of the most important antibiotics used in human medicine, topical application and used after surgical operations $(23,28)$. Bacitracin is also commonly used in animal and poultry feed additives which increases feed efficiency and reduce infectious diseases (14, 34). Despite its widespread use, bacitracin resistance is still scarce. It has also been reported that bacitracin has no negative impact on human health.

Many scientists had improved the bacitracin yields of Bacillus licheniformis by treating its vegetative cells with UV and chemical mutagens. Vegetative cells of Bacillus licheniformis SIPI 86-10 were treated with UV irradiation and then cultured on medium containing $\mathrm{Fe}^{+2}$ ions and pantothenic acid (26). Apart from bacitracin production, mutagens were used to enhance the production of Penicillin G, Phenyl-LAlanine and Actinomycin-D (19, 35, 39). Some workers treated Bacillus licheniformis cells with $0.5 \mathrm{M}$ ethyl methanesulphonate for three hours and cultured in a medium containing soybean meal, sucrose and mineral salts $(27,31)$. In another study vegetative cells of Bacillus licheniformis were exposed with N-methyl-N'-nitro-N-nitrosoguanidine by which bacitracin production was drastically increased (26). Better yield of bacitracin was obtained by treatment of cells with MNNG and suggested that blocking of alternative pathways of intermediates could increase the bacitracin production (9).

Due to wide spread use of bacitracin, it is necessary to find out ways and measures to reduce the cost of this product. To achieve this, our focus was to utilize random mutagenesis using physical (UV) and chemicals (MNNG and $\mathrm{HNO}_{2}$ ) to induce positive mutations in microbial DNA for enhanced production of bacitracin. By use of mutagens we have developed the hyper producing bacitracin strain Bacillus licheniformis UV-MN-HN-6. Appropriate fermentation technology and optimization of adequate control of fermentation processes was exploited to further enhance the yield of bacitracin. Biosynthesis of bacitracin was first reported by surface culture method (12). Effect of temperature (14), effect of $\mathrm{pH}$ (2), effect of organic acids (17), and effect of nitrogen and carbon sources (6) has been studied on the bacitracin production. Application of these parameters could increase the bacitracin production and could further minimize the product costs and allowed the small microbial factories to yield higher titers of bacitracin.

The present work was undertaken to develop Bacillus licheniformis mutant strain for the production of antibiotic bacitracin by utilizing physical and chemical mutagenesis. Following mutagenesis, various parameters for optimum production of bacitracin was also studied.

\section{MATERIALS AND METHODS}

\section{Bacillus licheniformis strain}

The cultures of Bacillus licheniformis were obtained from culture collection of Institute of Industrial Biotechnology, GC University, Lahore, that were previously isolated from poultry droppings collected from local habitat.

\section{Strain improvement by mutations}

In this study physical (UV) and chemical (MNNG and $\mathrm{HNO}_{2}$ ) mutagens were employed in systematic manner to obtain mutants that yield higher bacitracin production. For UV irradiation, method of Parekh et al., (32) was adopted. For chemical mutagenesis using $\mathrm{MNNG}$ and $\mathrm{HHO}_{2}$ method of Delic et al., (9) was followed.

\section{Combined effect of UV and chemical treatment}

The parental strain B. licheniformis GP-35 was treated with three mutagens (UV, MNNG and $\mathrm{HNO}_{2}$ ) consecutively. First the parental strain was subjected to UV irradiation $\left(1.2 \times 10^{2} \mathrm{~J} / \mathrm{m}^{2} \mathrm{~s}^{-1}\right)$ for 20 minutes. The mutant strain that produced maximum bacitracin was subjected to $1.5 \mathrm{mg} / \mathrm{ml}$ MNNG for 20 minutes. After this treatment, mutant strains 
obtained were screened for the bacitracin titer. The strain that yielded the better bacitracin production was then treated with $0.06 \mathrm{M} \mathrm{HNO}_{2}$ for 15 minutes. The survivals that produced better yield of bacitracin were selected. The flow sheet diagram of this scheme is shown in Figure 1.

\section{Inoculum preparation}

The inoculum was developed in $250 \mathrm{ml}$ conical flask containing $25 \mathrm{ml}$ medium having composition $\left(\mathrm{g} \mathrm{L}^{-1}\right)$; Peptone, 10; Glucose, 5; Beef extract, 5; $\mathrm{NaCl}, 2.5 ; \mathrm{MnCl}_{2}, 0.7$. The flask was incubated overnight at $37^{\circ} \mathrm{C}$ at $200 \mathrm{rpm}$. The $0.3 \mathrm{ml}$ (6\%) from the overnight culture was used to inoculate the 50 $\mathrm{ml} \mathrm{LB}$ medium in $250 \mathrm{ml}$ flask and was incubated at $37^{\circ} \mathrm{C}$ for 6-8 hours in rotary shaker at $250 \mathrm{rpm}$ until O.D 600 was reached at 1.5 .

\section{Effect of organic acids and phosphate sources}

The effect of different organic acids (tartaric acid, oxalic acid, lactic acid and gluconic acid) and different concentrations $(0.1 \%, 0.2 \%, 0.3 \%$ and $0.4 \%)$ of phosphate sources $\left(\mathrm{K}_{2} \mathrm{HPO}_{4}\right.$, $\mathrm{KH}_{2} \mathrm{PO}_{4}, \mathrm{NH}_{4} \mathrm{H}_{2} \mathrm{PO}_{4}$ and $\mathrm{Na}_{2} \mathrm{HPO}_{4}$ ) on bacitracin production was investigated at $37^{\circ} \mathrm{C}$, agitation speed $200 \mathrm{rpm}$ and initial $\mathrm{pH} 7.0$ for 48 hours.

\section{Effect of temperature and pH}

The effect of different incubation temperatures $(28,30$, $32,35,37,40,42,45$ and $\left.47^{\circ} \mathrm{C}\right)$ and various initial $\mathrm{pH}(4,5,6$, $7,8,9$, and 10 ) on production of bacitracin was also examined.

\section{Antibiotic Assay}

The activity of the extracts was analyzed by agar diffusion method (40). LB agar medium was autoclaved and $20 \mathrm{ml}$ of the medium was poured aseptically in the sterile petri plates and allowed to congeal. In the mean while, sterilized LB agar medium (assay medium) having $50-60^{\circ} \mathrm{C}$ temperature was inoculated with predetermined concentration of Micrococcus luteus (CN-5537) by using broth culture prepared by the inoculation of Micrococcus luteus. Four mililiter of the inoculated melted assay medium was spreaded uniformly over the first layer and allowed to solidify. The plates were refrigerated at $4^{\circ} \mathrm{C}$ and used according to the need. At the time of assay the plates were taken out from the refrigerator and 4 wells of $0.8 \mathrm{~cm}$ diameter were made in each plate aseptically with sterilized stainless steel bores of uniform edge and size. The pieces of agar from the digged wells were picked and removed with the help of sterilized loop. The two opposite wells were filled with the working standard of 1:4 dilutions and marked as $S_{1}$ and $S_{2}$, respectively. The remaining two were filled with the sample whose potency was to be determined in the same dilution (1:4) and marked $\mathrm{T}_{1}$ and $\mathrm{T}_{2}$ respectively. One hundred micro liter bacitracin standards as well as samples were poured with the help of micropipette in the digged holes. The plates were then placed carefully (to avoid spreading of solution due to tilting of the plates) in incubator for 18-24 hours at temperature $37^{\circ} \mathrm{C}$. Clear zones of inhibition were developed and diameter of zones of inhibition were measured and compared with the known standard.

The potency of the sample was calculated by the following formula:

i) Difference due to doses:

$$
\mathrm{E}=1 / 2\left[\left(\mathrm{~T}_{2}+\mathrm{S}_{2}\right)-\left(\mathrm{T}_{1}+\mathrm{S}_{1}\right)\right]
$$

ii) Difference due to sample:

$$
\mathrm{F}=1 / 2\left[\left(\mathrm{~T}_{2}+\mathrm{T}_{1}\right)-\left(\mathrm{S}_{1}+\mathrm{S}_{2}\right)\right]
$$

iii) Log ratio of doses:

$$
\mathrm{I}=\log 4
$$

iv) Slope:

$$
\begin{aligned}
& B=E / I \\
& M=F / B
\end{aligned}
$$

v) Potency ratio:

\section{Antilog M}

vi) Potency of sample $=$ Potency of standard $\mathrm{x}$ antilog $\mathrm{M}$ $=\mathrm{X}$ units $/ \mathrm{ml}$

where

$\mathrm{S}_{2}=$ Standard High (in concentration)

$\mathrm{S}_{1}=$ Standard Low (in concentration)

$\mathrm{T}_{2}=$ Test High

$\mathrm{T}_{1}=$ Test Low 


\section{Centrifugation}

Twenty milliliter of cell suspension of culture broth was centrifuged in a pre-weighed falcon tube at 10,000 rpm for 15 minutes. Dry cell mass of Bacillus licheniformis was determined by the method of Suzuki et al. (37).

\section{Kinetic Studies}

Kinetic parameters for batch fermentation experiments were determined according to the methods described by Pirt (33) and Lawford and Roseau (25). The values of specific growth rate were measured by dividing the values of plot of $\ln (\mathrm{X})$ by the time of fermentation. Product yield co-efficient $\mathrm{Y}_{\mathrm{p} / \mathrm{x}}$ was measured by dividing the values of ' $\mathrm{dP}$ ' by the values of ' $\mathrm{dX}$ '. The volumetric rates for product formation $\left(\mathrm{Q}_{\mathrm{p}}\right)$ was determined by dividing the values obtained from the maximum slopes in plots of bacitracin produced by the time of fermentation. The volumetric rates for biomass formation $\left(Q_{x}\right)$ were measured by dividing the values of maximum slope in plot of cell mass by the incubation time. The specific rate constant for bacitracin formation $\left(\mathrm{q}_{\mathrm{p}}\right)$ was determined by multiplying the values obtained for $\mu$ with the values obtained for $\mathrm{Y}_{\mathrm{p} / \mathrm{x}}$.

\section{RESULTS}

\section{Bacillus licheniformis strains}

Bacillus licheniformis designated as GP-35 was previously isolated from poultry droppings. The bacitracin activity of this strain was determined by measuring the zone of inhibition of Micrococcus luteus that came out to be $14 \pm 0.72 \mathrm{IU} / \mathrm{ml}$.

\section{Strain improvement by mutagens}

UV irradiation: After UV exposure for different time periods (5-30 minutes), survival mutants were screened for bacitracin production in comparison with control (cells without exposure). Out of 124 mutant strains, 19 (14\%) mutant strains were selected that yielded increased bacitracin production in comparison to wild type strain. Maximum bacitracin production $\left(23 \pm 0.69 \mathrm{IU} \mathrm{ml}^{-1}\right)$ was observed after 20 minutes for mutant strain designated as GP-UV-11 (Table 1).

Table 1. Effect of UV, MNNG and $\mathrm{HNO}_{2}$ on bacitracin production of mutant strain

\begin{tabular}{|c|c|c|c|c|c|}
\hline Mutagen & Concentration & $\begin{array}{c}\text { Time of } \\
\text { treatment }(\mathrm{min})\end{array}$ & $\begin{array}{c}\text { Total number of } \\
\text { screened survivors }\end{array}$ & $\begin{array}{l}\text { Over-producing } \\
\text { clones of bacitracin }\end{array}$ & $\begin{array}{l}\text { Maximum production } \\
\text { of bacitracin by mutant }\end{array}$ \\
\hline UV & $1.2 \times 10^{2} \mathrm{~J} / \mathrm{m}^{2} \mathrm{~s}^{-1}$ & $5-30$ & 124 & $19(14 \%)$ & $\begin{array}{c}\text { GP-UV-11 } \\
23 \pm 0.69 \mathrm{IU} \mathrm{ml}^{-1}\end{array}$ \\
\hline MNNG & $1.0-2.0 \mathrm{mg} \mathrm{ml}^{-1}$ & $5-30$ & 253 & $29(11.4 \%)$ & $\begin{array}{l}\text { GP-MNNG-23 } \\
31 \pm 0.79 \mathrm{IU} \mathrm{ml}^{-1}\end{array}$ \\
\hline $\mathrm{HNO}_{2}$ & $0.04-0.08 \mathrm{M}$ & $2-60$ & 331 & $36(10.8 \%)$ & $\begin{array}{c}\text { GP-HN-27 } \\
26 \pm 0.89 \mathrm{IU} \mathrm{ml}^{-1}\end{array}$ \\
\hline
\end{tabular}

\section{Nitrous acid}

The parent strain B. licheniformis GP-35 was also subjected to nitrous acid $\left(\mathrm{HNO}_{2}\right)$ for 2-60 minutes. The survival colonies were tested for bacitracin production. Out of 331 mutant strains only $36(10.8 \%)$ colonies produced higher bacitracin yield than parental strain. Maximum bacitracin $\left(26 \pm 0.89 \mathrm{IU} \mathrm{ml}^{-1}\right)$ was produced by mutant strain designated as GP-HN-27 (Table 1).

\section{Combined effect of UV and chemical treatment}

The parental strain B. licheniformis GP-35 was also treated with all the three mutagens (UV, MNNG and $\mathrm{HHO}_{2}$ ) consecutively. Mutant strain GP-UV-11 (26 \pm 0.69 IU ml $\left.{ }^{-1}\right)$ obtained after UV treatment (Table 1) was subjected to $1.5 \mathrm{mg}$ $\mathrm{ml}^{-1}$ MNNG for 20 minutes. Survivals were tested and maximum bacitracin production $\left(35 \pm 1.35 \mathrm{IU} \mathrm{ml}^{-1}\right)$ obtained from mutant strain designated as B. licheniformis UV-MN-5. 
The vegetative cells of this strain were further treated with $0.06 \mathrm{M} \mathrm{HNO}_{2}$ for 15 minutes. Survivals were tested and better bacitracin production $\left(41.6 \pm 0.92 \mathrm{IU} \mathrm{ml}^{-1}\right)$ was obtained by strain designated as B. licheniformis UV-MN-HN-6. The flow sheet diagram of this scheme and mutants obtained is shown in Figure 1. The Comparison of wild and mutant strain with respect to cell mass production is shown in Table 2.

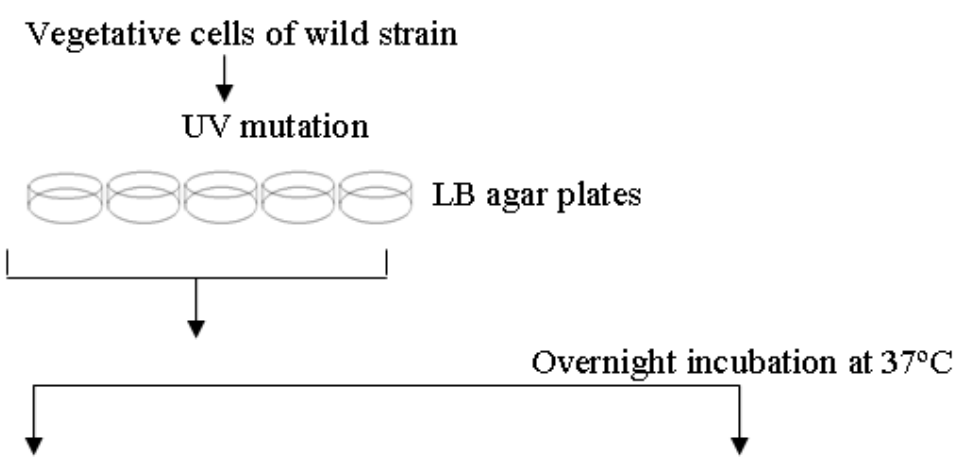

Mutants producing lower yield Mutant GP-UV-11 producing maximum yield of bacitracin were discarded of bacitracin $(23 \pm 0.69 \mathrm{mg} / \mathrm{ml})$ was selected

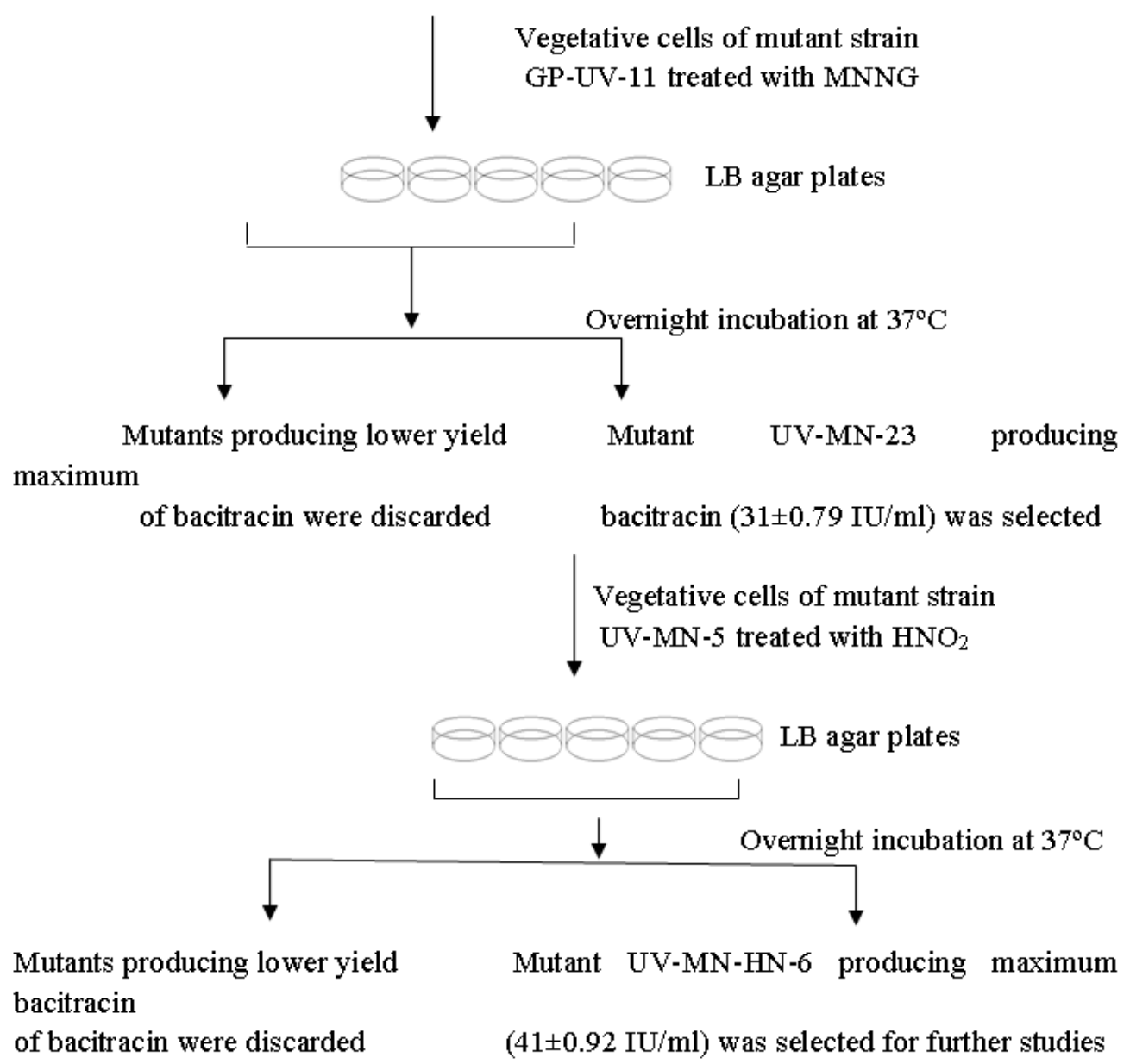

Figure 1. Adopted strategy for screening of B. licheniformis UV-MN-HN-6 survivors that over produce bacitracin following mutations by UV, MNNG and $\mathrm{HNO}_{2}$. 
Table 2. Comparison of wild and mutant strain with respect to cell mass production.

\begin{tabular}{ccc}
\hline $\begin{array}{c}\text { Incubation } \\
\text { time (hours) }\end{array}$ & \multicolumn{2}{c}{ Cell mass (mg ml $\left.^{-\mathbf{1}}\right)$} \\
\cline { 2 - 3 } & $\begin{array}{c}\text { Wild strain } \\
\text { B. licheniformis } \\
\text { GP-35) }\end{array}$ & $\begin{array}{c}\text { Mutant strain } \\
(\text { B. licheniformis } \\
\text { UV-MN-HN-6) }\end{array}$ \\
\hline 6 & 0.095 & 0.089 \\
12 & 0.145 & 0.152 \\
18 & 0.266 & 0.244 \\
24 & 0.298 & 0.283 \\
30 & 0.333 & 0.317 \\
36 & 0.327 & 0.322 \\
42 & 0.334 & 0.330 \\
48 & 0.345 & 0.339 \\
\hline
\end{tabular}

\section{Stability studies of mutant strain}

Overproducing mutant strain $B$. licheniformis UV-MNHN-6 obtained by the above systematic screening was studied for its stability for bacitracin production for a period of 6 months (15 generations). Mutant strain was inoculated on LB agar after fermentation and used for inoculating next batch. The mutant strain was found to be very stable in terms of bacitracin production (Table 3 ).

Table 3. Validation of the stability of the mutant strain $B$. licheniformis UV-MN-HN-6.

\begin{tabular}{cc}
\hline $\begin{array}{c}\text { No. of generations of } \boldsymbol{B} \text {. } \\
\text { licheniformis } \mathbf{U V}-\mathbf{M N}-\mathbf{H N}-6\end{array}$ & $\begin{array}{c}\text { Bacitracin } \\
\text { production }\left(\mathbf{I U} \mathbf{~ m l}^{\mathbf{- 1}}\right)\end{array}$ \\
\hline $1^{\text {st }}$ & 43 \\
$2^{\text {nd }}$ & 42 \\
$3^{\text {rd }}$ & 43 \\
$4^{\text {th }}$ & 41 \\
$5^{\text {th }}$ & 43 \\
$6^{\text {th }}$ & 41 \\
$7^{\text {th }}$ & 43 \\
$8^{\text {th }}$ & 42 \\
$9^{\text {th }}$ & 43 \\
$10^{\text {th }}$ & 43 \\
$11^{\text {th }}$ & 42 \\
$12^{\text {th }}$ & 41 \\
$13^{\text {th }}$ & 43 \\
$14^{\text {th }}$ & 42 \\
$15^{\text {th }}$ & 43 \\
\hline
\end{tabular}

\section{Kinetic parameters of mutant strains}

The mutant strain B. licjeniformis UV-MN-HN-6 was compared with the parental strain B. licheniformis GP-35 for the productions of bacitracin. There was significant enhancement in the antibiotic production by the mutant strain. It is clear from the table 1 that the yield of the antibiotic per gram substrate consumption and per gram cell mass formation was about 2.5 times more than the parental strain. The values of $\mathrm{Q}_{\mathrm{p}}, \mathrm{Q}_{\mathrm{s}}$ and $\mathrm{Q}_{\mathrm{x}}$ by the parental and mutant strain were 12.55, 1.9, 1.34 and 37.75, 3.10 and 1.97 respectively (Table 4). Each value is an average of three replicates. Kinetic parameters clearly indicate that mutant strain produced much higher yield of bacitracin than parent strain.

Table 4. Comparison of wild and mutant strain by kinetic study

\begin{tabular}{ccc}
\hline $\begin{array}{c}\text { Kinetic } \\
\text { parameters }\end{array}$ & $\begin{array}{c}\text { Parental strain } \\
\text { (B. licheniformis } \\
\text { GP-35) }\end{array}$ & $\begin{array}{c}\text { Mutant strain } \\
\text { (B. licheniformis UV- } \\
\text { MN-HN-6) }\end{array}$ \\
\hline $\mathrm{Y}_{\mathrm{p} / \mathrm{s}}(\mathrm{IU} / \mathrm{g}$ & $16 \pm 0.72^{\mathrm{ab}} \mathrm{IU} / \mathrm{g}$ & $43.6 \pm 1.21^{\mathrm{ac}} \mathrm{IU} / \mathrm{g}$ \\
substrate) & & \\
$\mathrm{Y}_{\mathrm{p} / \mathrm{x}}(\mathrm{IU} / \mathrm{g}$ cells $)$ & $60.86 \pm 1.42^{\mathrm{de}} \mathrm{IU} / \mathrm{g}$ & $151 \pm 2.14^{\mathrm{ab}} \mathrm{IU} / \mathrm{g}$ \\
$\mathrm{Y}_{\mathrm{x} / \mathrm{s}}(\mathrm{g}$ cells/g) & $0.70 \pm 0.07^{\mathrm{cd}} \mathrm{g}$ & $0.72 \pm 0.09^{\mathrm{cd}} \mathrm{g} \mathrm{cells} / \mathrm{g}$ \\
$\mathrm{Q}_{\mathrm{p}}(\mathrm{IU} / \mathrm{ml} / \mathrm{h})$ & $\begin{array}{c}12.55 \pm 0.31^{\mathrm{ae}} \\
\mathrm{IU} / \mathrm{ml} / \mathrm{h}\end{array}$ & $37.75 \pm 1.33^{\mathrm{ad}} \mathrm{IU} / \mathrm{ml} / \mathrm{h}$ \\
$\mathrm{Q}_{\mathrm{s}}(\mathrm{g} / \mathrm{l} / \mathrm{h})$ & $1.90 \pm 0.09^{\mathrm{ad}} \mathrm{g} / \mathrm{l} / \mathrm{h}$ & $2.10 \pm 0.1^{\mathrm{ab}} \mathrm{g} / \mathrm{l} / \mathrm{h}$ \\
$\mathrm{Q}_{\mathrm{x}}(\mathrm{g}$ cells $/ \mathrm{l} / \mathrm{h})$ & $1.34 \pm 0.076^{\mathrm{ae}} \mathrm{g}$ & $1.97 \pm 0.069^{\mathrm{ac}} \mathrm{g} \mathrm{cells} / \mathrm{l} / \mathrm{h}$ \\
& cells/l/h \\
\hline
\end{tabular}

Each value is a mean of three replicates. Values followed by different letters differ significantly at $p \leq 0.05$.

$\mathrm{Y}_{\mathrm{p} / \mathrm{s}}=$ antibiotic produced $/ \mathrm{g}$ substrate consumed. $\mathrm{Y}_{\mathrm{p} / \mathrm{x}}=$ antibiotic produced/g cell mass formation. $\mathrm{Y}_{\mathrm{x} / \mathrm{s}}=\mathrm{g}$ cells produced/g substrate consumed. $\mathrm{Q}_{\mathrm{p}}=$ antibiotic produced $/ \mathrm{l} / \mathrm{h}$. $\mathrm{Q}_{\mathrm{s}}=\mathrm{g}$ substrate consumed $/ \mathrm{l} / \mathrm{h} . \mathrm{Q}_{\mathrm{x}}=\mathrm{g}$ cell mass formation $/ \mathrm{l} / \mathrm{h}$.

\section{Optimization of fermentation parameters}

Various parameters were optimized during this study to obtain better bacitracin production.

Effect of organic acids and phosphate sources: Maximum bacitracin production for mutant and wild strain was obtained as $47 \pm 1.06 \mathrm{IU} / \mathrm{ml}$ and $20 \pm 0.48 \mathrm{IU} \mathrm{ml}^{-1}$ respectively after addition of citric acid at concentration of $1.0 \mathrm{gL}^{-1}$ (Figure 2 A). The bacitracin titer was further increased and reached at 
$51.5 \pm 1.47 \mathrm{IU} \mathrm{ml}^{-1}$ and $23 \pm 0.47 \mathrm{IU} \mathrm{ml}^{-1}$ respectively for mutant production medium (Figure $2 \mathrm{~B}$ ). and wild strain when $0.2 \% \quad \mathrm{KH}_{2} \mathrm{PO}_{4}$ was added in the

A

B acitracin production (M utant, $0.5 \mathrm{~g} / \mathrm{L}$ )

B acitrac in production (M utant, $1.5 \mathrm{~g} / \mathrm{L}$ )

B acitracin production (Wid. $1.0 \mathrm{~g} / \mathrm{L}$ )

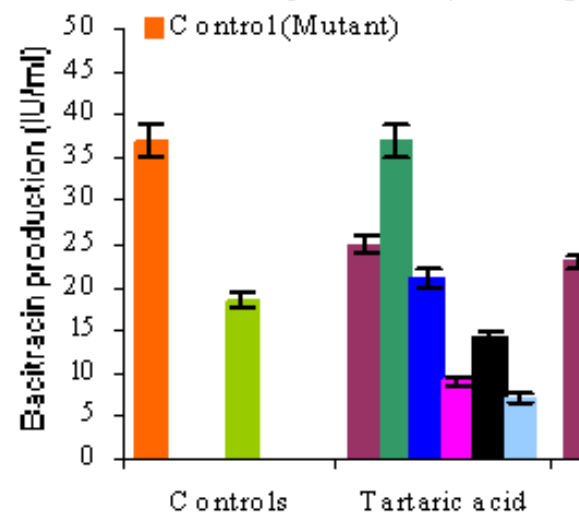

B

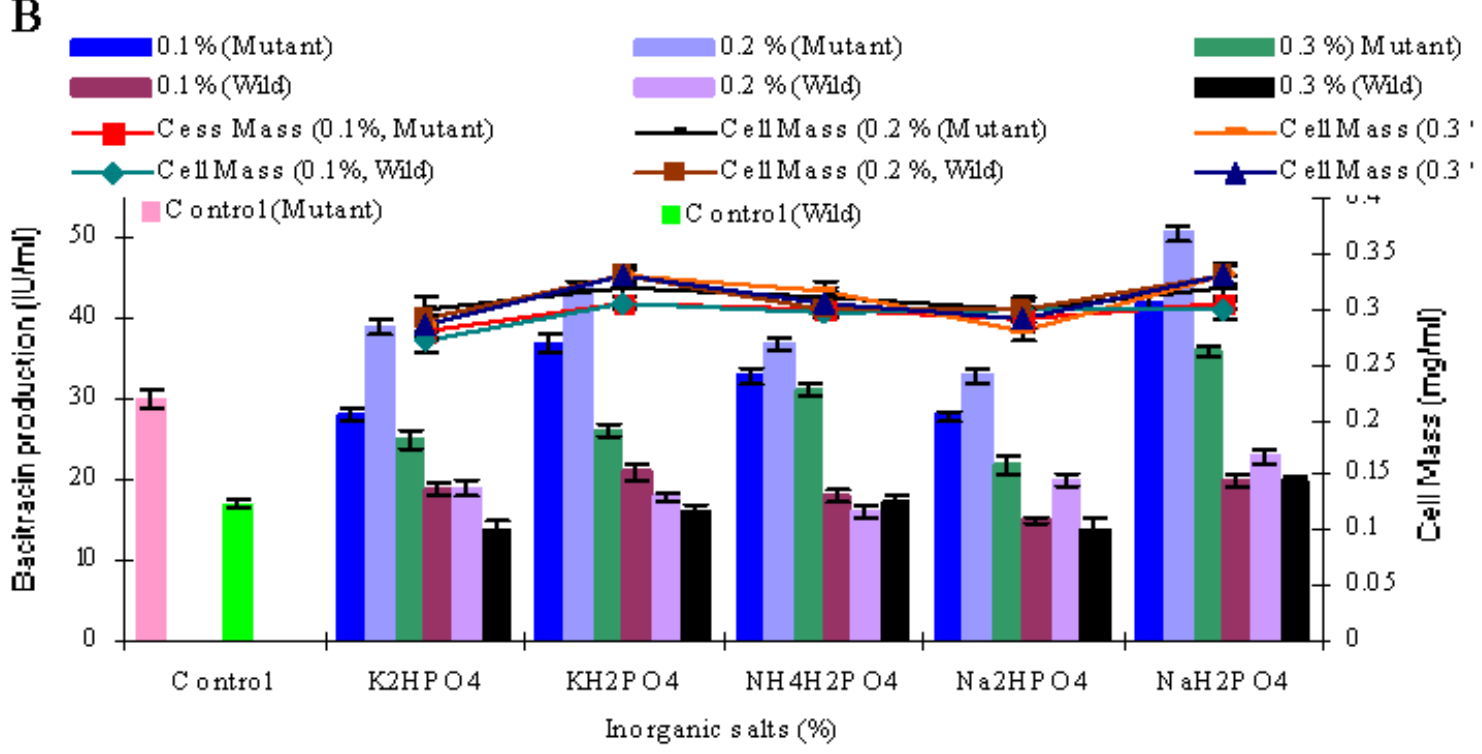

Figure 2. Effect of (A) different organic acids (B) Inorganic acids on the production of bacitracin by mutant strain B. licheniformis UV-MN-HN-6 and parental strain B. licheniformis GP-40 in shake flask at $37^{\circ} \mathrm{C}$ after 48 hours of incubation.

Effect of temperature and pH: It was observed that at temperature $37^{\circ} \mathrm{C}$, maximum bacitracin yield of $55.8 \pm 2.06 \mathrm{IU}$ $\mathrm{ml}^{-1}$ and $25.3 \pm 1.04 \mathrm{IU} \mathrm{ml}^{-1}$ was obtained for mutant and wild strain respectively (Figure $3 A$ ). The values for $\mathrm{Y}_{\mathrm{p} / \mathrm{s}}, \mathrm{Y}_{\mathrm{p} / \mathrm{x}}, \mathrm{Y}_{\mathrm{x} / \mathrm{s}}$,

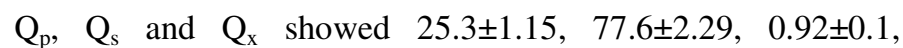
$15.4 \pm 0.79,1.93 \pm 0.13$ and $52.9 \pm 1.43,181 \pm 2.35,0.81 \pm 0.09$, $47.1 \pm 0.68,2.65 \pm 0.19$ for both wild and mutant strain. Optimization of $\mathrm{pH}$ value of the fermentation medium further 
increased the bacitracin production of wild and mutant strains. At $\mathrm{pH} 7.0$, bacitacin production reached at $59.1 \pm 1.35 \mathrm{IU} \mathrm{ml}^{-1}$ and $27 \pm 0.93 \mathrm{IU} \mathrm{ml}^{-1}$ for mutant and wild strain respectively (Figure 3B). The values for $\mathrm{Y}_{\mathrm{p} / \mathrm{s}}, \mathrm{Y}_{\mathrm{p} / \mathrm{x}}, \mathrm{Y}_{\mathrm{x} / \mathrm{s}}, \mathrm{Q}_{\mathrm{p}}, \mathrm{Q}_{\mathrm{s}}$ and $\mathrm{Q}_{\mathrm{x}}$ showed $27.9 \pm 1.15,78.2 \pm 2.29,0.97 \pm 0.1,16.2 \pm 0.79,2.26 \pm 0.17$ and $55.4 \pm 1.32,189.3 \pm 2.2,0.88 \pm 0.09,50.4 \pm 0.73,2.75 \pm 0.21$ for both wild and mutant strain.

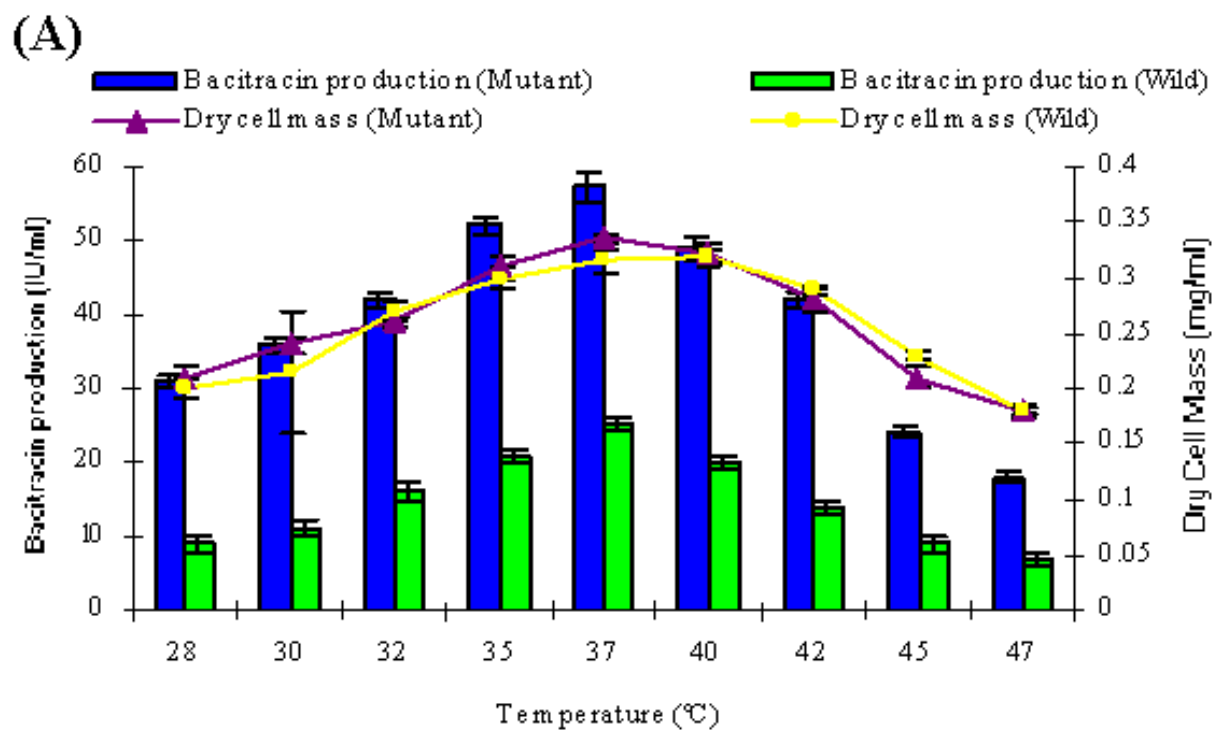

(B)
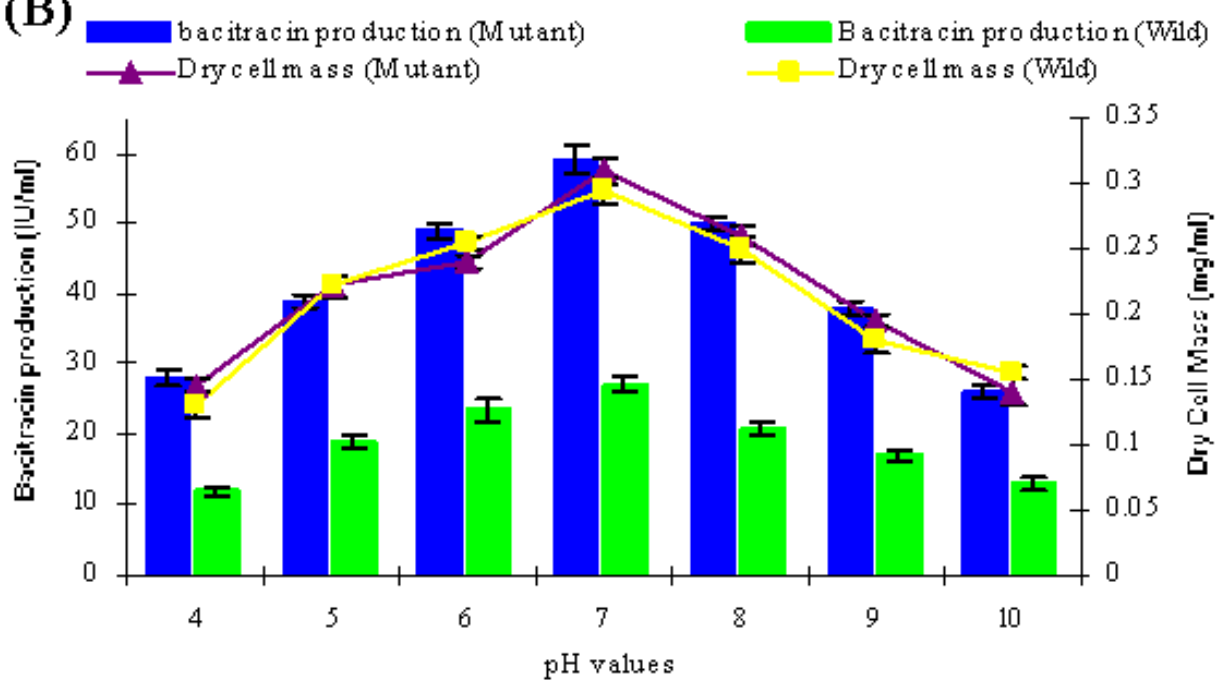

Figure 3. Effect of (A) temperature and (B) $\mathrm{pH}$ on the production of bacitracin by $B$. licheniformis UV- MN-HN-8 and wild strain $B$. licheniformis GP-35 in shake flask at $37^{\circ} \mathrm{C}$ after 48 hours of incubation.

\section{DISCUSSION}

The present work was about the explanation of the mutant strain of Bacillus licheniformis that produced hyper production of bacitracin and optimization of various fermentation parameters. Bacitracin is mainly produced by Bacillus licheniformis $(13,30)$. We used locally isolated strain of Bacillus licheniformis to obtain mutants that can produce high titers of bacitracin. In the strategy 
adopted to improve Bacillus licheniformis strains, classical mutagenesis was applied. Therefore, amongst various mutagens causing multiplicity of mutations (32), UV and nitrous acid were employed in addition to MNNG.

Irradiation of vegetative cells of wild type strain $B$. licheniformis GP-35 produced only 19 (14\%) mutant strains that gave increased bacitracin production as compared to wild type strain $\left(14 \pm 0.72 \mathrm{IU} \mathrm{ml}^{-1}\right)$. Maximum bacitracin production $\left(23 \pm 0.69 \mathrm{IU} \mathrm{ml}^{-1}\right)$ was observed for mutant strain designated as GP-UV-11. Previous studies showed that vegetative cells of Bacillus licheniformis were improved by UV irradiation (26). Exposure of wild type strain to different concentrations (1.0$2.0 \mathrm{mg} \mathrm{ml}^{-1}$ ) of MNNG for 5-30 minutes produced only 29 $(11.4 \%)$ mutant strains that produced higher yield of bacitracin in comparison with wild type strain. Out of these Bacillus licheniformis GP-MNNG-23 produced best yield of bacitracin $\left(31 \pm 0.79 \mathrm{IU} \mathrm{ml}^{-1}\right)$ (Table 1). Likewise, 36 (10.8\%) mutant strains were obtained that produce higher bacitracin yield than parental strain when cells were treated with 0.04-0.08 $\mathrm{M} \mathrm{HNO}_{2}$ for different time intervals (Table 1). Maximum bacitracin production $\left(26 \pm 0.89 \mathrm{IU} \mathrm{ml}^{-1}\right)$ was obtained by Bacillus licheniformis GP-HN-27. The mutagenesis studies showed that all mutagens (UV, MNNG and $\mathrm{HNO}_{2}$ ) helped to develop mutant strains that gave better yield of bacitracin than the wild strain. An increased production of bacitracin was demonstrated after exposure of $B$. licheniformis cells to chemical mutagen (31).

Much higher yield of bacitracin was obtained when the same vegetative cells of $B$. licheniformis GP-35 were treated with UV, MNNG and $\mathrm{HNO}_{2}$ one by one as compared to mutant strains that were obtained by treatment of vegetative cells by mutagens separately. In this strategy (Figure 1) B. licheniformis UV-MN-HN-6 produced best yield of bacitracin (41.6 \pm 0.92 IU $\left.\mathrm{ml}^{-1}\right)$. Similar results regarding mutagenesis were reported (1, 7).

It has been observed that wild strain and their mutants showed similar general characters. The colonies of mutant strain showed distinct circular and opaque morphology similar to that of wild strain. No unusual phenotype was detected after mutation. No difference in the growth of both wild type and mutant strain was observed as assessed by measurement of biomass (Table 2). This result indicates that the enhancement of antibiotic production by the mutant strain is not due to increase in growth but due to the enhancement in production of the antibiotic. It was also observed that this mutant was highly stable upto 15 generations tested in a time period of about 6 months. It might be due to permanent change in DNA sequence caused by $\mathrm{MNNG}$ and $\mathrm{HNO}_{2}$ or might be due to stabilization of pre-induced UV mutation by these mutagens (Table 3).

All kinetic parameters studied clearly indicate the difference between the parental strain B. licheniformis GP-35 and the mutant strain B. licheniformis UV-MN-HN-6 (Table 4). These parameters were considered as the factors that might control bacitracin synthesis. The antibiotic production per gram substrate consumed $\left(\mathrm{Y}_{\mathrm{p} / \mathrm{s}}\right)$ shows $16 \pm 0.72 \mathrm{IU} \mathrm{g}^{-1}$ and $43.6 \pm 0.92$ IU $\mathrm{g}^{-1}$ for parental and mutant strain respectively indicating higher production of antibiotic by mutant strain. Specific antibiotic yield $\left(\mathrm{Y}_{\mathrm{p} / \mathrm{x}}\right)$ was $60.86 \pm 1.42 \quad \mathrm{IU} \mathrm{g}^{-1}$ cells and $151 \pm 2.14 \mathrm{IU} \mathrm{g}^{-1}$ cells for parent and mutant strain respectively indicating that specific antibiotic yield is much higher for mutant strain as compared to parent strain. The maximum growth for mutant strain in terms of volumetric rate for cell mass formation $\left(\mathrm{Q}_{\mathrm{x}}\right), 48 \mathrm{~h}$ after the incubation was slightly higher from wild strain. This indicates that growth is not the key factor for the enhanced production of bacitracin by the mutant strain. Antibiotic production rate $\left(\mathrm{Q}_{\mathrm{p}}\right)$ for mutant strain was almost three times higher $\left(37.75 \pm 1.33 \mathrm{IU} \mathrm{m}^{-1} \mathrm{~h}^{-1}\right)$ than that of wild strain $\left(12.55 \pm 0.31 \mathrm{IU} \mathrm{m} \mathrm{m}^{-1} \mathrm{~h}^{-1}\right)$ indicating that mutagenesis has increased the production rate rather than the biomass production. As far as gram substrate consumed $\left(\mathrm{Q}_{\mathrm{s}}\right)$ and cell mass formation is $\left(Q_{x}\right)$ concerned, mutant strain has slight faster rate both for substrate consumption and cell mass formation. $\mathrm{Y}_{\mathrm{x} / \mathrm{s}}$ values for both parent and mutant strain shows that both have almost same rate for cells production indicating some genetic change in the genome of mutant strain after exposure to mutagens that allow mutant strain to produce 
higher concentration of bacitracin. Rather it was not any morphological change in which rate of cell production or size of cells has increased. Kinetic parameters like $\mathrm{Y}_{\mathrm{p} / \mathrm{s}}, \mathrm{Y}_{\mathrm{p} / \mathrm{x}}$ and $\mathrm{Q}_{\mathrm{p}}$ for mutant strain was also studied earlier by various workers (4, 38).

Optimization of various parameters also increased the bacitracin production. Organic acids play an important role in the bacitracin production. Addition of lactic acid in the medium increased the bacitracin production by mutant strain upto a level of $47 \pm 1.06 \mathrm{IU} \mathrm{ml}^{-1}$ (Figure $2 \mathrm{~A}$ ). Similar results were obtained by Supek et al., (36) and Haavik (17). Addition of $0.2 \% \mathrm{KH}_{2} \mathrm{PO}_{4}$ in the production medium increased the bacitracin production upto $51.5 \pm 1.47 \mathrm{IU} \mathrm{ml}^{-1}$ by mutant strain (Figure $2 \mathrm{~B}$ ). The results obtained are in accordance with the results obtained by Haavik (16), Demain (10). Maximum bacitracin production (55.8 $\pm 2.06 \mathrm{IU}$ $\mathrm{ml}^{-1}$ ) by mutant strain was achieved at temperature $37^{\circ} \mathrm{C}$. By increasing or decreasing the temperature, the bacitracin production dropped sharply. This phenomenon may be due to the fact that rate of all metabolic processes increased by increase in temperature but these metabolic processes decreased after certain temperature limits and high temperature has inhibitory effect on the growth of microorganisms (8). Our results were also in agreement with the result obtained by Bushra et al. (6). Slight increase in the bacitracin production was also observed when initial $\mathrm{pH}$ of the medium was optimized. Maximum bacitracin production $\left(59.1 \pm 1.35 \mathrm{IU} \mathrm{ml}^{-1}\right)$ by mutant strain (B. licheniformis UV-MN$\mathrm{HN}-6)$ and wild strain $\left(27 \pm 0.93 \mathrm{IU} \mathrm{ml}^{-1}\right)$ was obtained at $\mathrm{pH} 7.0$, both low and high $\mathrm{pH}$ values inhibit bacitracin production (Figure 4 A). Change in $\mathrm{pH}$ might have affected the basal metabolism of the organism that resulted in decreased growth and low bacitracin production. It might have altered the structure and function of the antibiotic and thus retarded its activity. Similar results with respect to $\mathrm{pH}$ optimization were obtained in the previous study (15).

\section{CONCLUSION}

The stable mutant strain B. licheniformis is achieved after mutagenesis studies and optimization of various parameters that produce high yield of bacitracin.

\section{REFERENCES}

1. Adelberg, E.A.; Mandel, M.; Chen, G.C.C. (1965). Optimal conditions for mutagenesis by $\mathrm{N}$-methyl-N'-nitro-N-nitrosoguanidine in E. coli, $\mathrm{K}$ 12. Biochem Biophy Acta Res Commun, 18, 788-795.

2. Awais, M.; Pervez, A.; Sadia, Q.; Saleem, M. (2008). Effects of glucose, incubation period and $\mathrm{pH}$ on the production of peptide antibiotics by Bacillus pumilus. Af J Microbiol Res, 2, 114-119.

3. Azevedo, E.C.; Rios, E.M.; Fukushima, K.; Campos-Takaki, G.M. (1993). Bacitracin production by a new strain of Bacillus subtilis. Extraction, purification, and characterization. Appl Biochem Biotechnol, 42, 1-7.

4. Bokhari, S.A.I; Latif, F.; Rajoka, M.I. (2008). Kinetics of high-level of ß-glucosidase production by a 2-deoxyglucose-resistant mutant of Humicola lanuginosa in submerged fermentation. Braz. J. Microbiol, 39:724-733.

5. Brewer, G.A.; Florey, K. (1980). Analytical profiles of drug substances. New York: Academics, p 69.

6. Bushra, J.; Fariha, H.; Hameed, A.; Safia, A. (2007). Isolation of Bacillus subtilis MH-4 from soil and its potential of polypeptidic antibiotic production. Pak J Pharm Sci, 20(1), 26-31.

7. Calam, C. (1964). The selection, improvement and preservation of microorganism. Prog Ind Microbiol, 5, 3-53.

8. Cladera-Olivera, F.; Caron, G.R.; Brandell, A. (2004). Bacteriocin production by Bacillus licheniformis strain P40 in cheese whey using response surface methodology. Biochem Eng J, 21(1), 53-58.

9. Delic, V.; Hopwood, D.A.; Friend, E.J. (1970). Mutagenesis by Nmethyl-N'-nitro-N-nitrosoguanidine (NTG) in Streptomyces coelicolor. Mutant Res, 9 (2), 167-182.

10. Demain, A.L. (1968). Regulatory mechanisms and the industrial production of microbial metabolites. Lloydia 31, 395-418.

11. Donoso, J.; Craig, G.O.; Baldwin, R.S. (1970). The distribution and excretion of zinc bacitracin-14C in rats and swine. Toxicol Appl Pharmacol, 17, 366-374.

12. Flickinger, M.C.; Perlman, D. (1979). Application of oxygen-enriched aeration in the production of bacitracin by Bacillus licheniformis. Antimicrob Agents Chemother, 15, 282-293.

13. Gavrilescu, M.; Roman, R.V. (1993). Investigation of the bacitracin biosynthesisin an airlift bioreactor. Acta Biotechnol., 13, 161-175.

14. Hampson, D.J.; Phillips, N.D.; Pluske, J.R. (2002). Dietary enzyme and zinc bacitracin reduce colonisation of layer hens by the intestinal spirochaete Brachyspira intermedia. Vet Microbiol, 86, 351-360.

15. Haddar, H.O.; Aziz, G.M.; Al-Gelawi, M.H. (2007). Optimization of bacitracin production by Bacillus licheniformis B5. Pak J Biol Sci, 10, 972-976.

16. Haavik, H.I. (1974a). Studies on the formation of bacitracin by Bacillus 
licheniformis: effect of inorganic phosphate. J Gen Microbiol, 84, 226230.

17. Haavik, H.I. (1974b). Studies on the formation of bacitracin by Bacillus licheniformis: role of catabolite repression and organic acids. J Gen Microbiol, 84, 321-326.

18. Ikai, Y.; Oka, H.; Hayakawa, J.; Harada, K. I. and Suzuki, M. (1992). Structural characterization of bacitracin components by Frit-fast atom bombardment (FAB) liquid chromatography/mass spectrometry (LC/MS). J Antibiot. 45(8): 1325-34.

19. Ikram, U.I.; Ali, S. (2006). Mutation of Aspergillus oryzae for improved production of 3, 4- dihydroxy Phenyl-L-Alanine (L-Dopa) from LTyrosine. Braz J Microbiol. 37:78-86.

20. Ishihara, H.; Takoh, M.; Nishibayashi, R.; Sato, A. (2002). Distribution and variation of bacitracin synthetase gene sequences in laboratory stock strains of Bacillus licheniformis. Curr Microbiol, 45, 18-23.

21. Johnson, B.A.; Anker, H.; Meleney, F.L. (1945). Bacitracin: a New Antibiotic Produced by a Member of the B. subtilis Group. Science, 102, 376-377.

22. Kang, J.W.; De Reymaeker, G.; Van Schepdael, A.; Roets, E.; Hoogmartens, J. (2001). Analysis of bacitracin by micellar electrokinetic capillary chromatography with mixed micelle in acidic solution. Electrophoresis, 22 (7), 1356-62.

23. Katz, B.E.; Fisher, A.A. (1987). Bacitracin: a unique topical antibiotic sensitizer. J Am Acad Dermatol 17(6): 1016-24.

24. Konz, D.; Klens, A.; Schorgendorfer, K.; Marahiel, M.A. (1997). The bacitracin biosynthesis operon of Bacillus licheniformis ATCC 10716: molecular characterization of three multi-modular peptide synthetases. Chem Biol, 4, 927-937.

25. Lawford, H.G.; Roseau, J.D. (1993). Mannose fermentation by ethanologenic recombinants of Escherichia coli and kinetical aspects. Biotechnol. Lett., 15:615-620.

26. Liyong, H.; Youli, S.; Tong, C. (1988). Rational screening: Effects of ferrous sulfate or pantothenic acid on high-yielding mutants of Bacillus licheniformis. Yiyo Gongye, 19 (1), 4-8 (CA 108: 12999b 11988).

27. Lukin, A.A.; Rozov, A.N.; Planutiene, M.C. (1986). Synthesis and sporulation in Bacillus licheniformis mutants with lower proteolytic activity. Antibiot. Med. Biotechnol. 31(6): 405-408.

28. MacIver, R.H.; Stewart, R.; Frederiksen, J.W.; Fullerton, D.A.; Horvath,
K.A. (2006). Topical application of bacitracin ointment is associated with decreased risk of mediastinitis after median sternotomy. Heart Surg Forum, 9, E750-753.

29. Ming, L.J.; Epperson, J.D. (2002). Metal binding and structure-activity relationship of the metalloantibiotic peptide bacitracin. J Inorg Biochem 91(1): 46-58.

30. Murphy, T.; Roy, I.; Harrop, A.; Dixon, K.; Keshavarz, T. (2007). Effect of oligosaccharide elicitors on bacitracin A production and evidence of transcriptional level control. J Biotechnol, 131, 397-403.

31. Paleckova, F.; Smekal, F. (1981). Cultivation of Bacillus licheniformis for increasing the yield of bacitracin., Czeck Pat. C. S. 194, 329 (CA 96: 141202).

32. Parekh, S.; Vinci, V.A.; Strobel, R.J. (2000). Improvement of microbial strains and fermentation processes. Appl Microbiol Biotechnol, 54, 287301.

33. Pirt, S.J. (1975). Principles of cell and microbe and cell cultivation. Blackwell Scientific. Oxford., pp: 4-22.

34. Prescott, J.F.; Baggot, J.D. (1993). Antimicrobial therapy in veterinary medicine. 2nd ed. Iowa State University Press, Ames, 612.

35. Rubina, A.; Shafqat, F.; Syed, S.A. (2010). Improvement of Penicillin G acylase expression in Escherichia coli through UV induced mutations. Braz J Microbiol. 41: 1133-1141.

36. Supek, V.; Gamulin, S.; Delic, V. (1985). Enhancement of bacitracin biosynthesis by branched-chain amino acids in a regulatory mutant of Bacillus licheniformis. Folia Microbiol 30, 342-348.

37. Suzuki, Y.; Kishigami, T.; Abe, S. (1976). Production of extracellular alpha-glucosidase by a thermophilic Bacillus species. Appl Environ Microbiol, 31, 807-812.

38. Tehreema, I.; Mubashir, N.; Muhammad, A.Z.; Ikram, U.I. (2010). Production of extracellular lipases by Rhizopus oligosporus in a stirred fermentor. Braz. J. Microbiol.41:4 São Paulo. doi: 10.1590/S151783822010000400034 .

39. Vandana, P.; Tripathi, C.K.M.; Vinod, B.; Srivastava, S.C. (2008). Production of actinomycin-D by the mutant of a new isolate of Streptomyces sindenensis. Braz J Microbiol. 39:689-692.

40. William, H. (1977). Microbiological Assay: An introduction to quantitative principles and evaporation. Academic Press Inc. New York, 34-35. 